\title{
Synthesis and Characterization of Three New di-n-butyl [bis (alkyl-aminopropionic acid)] tin (IV)
}

\author{
Nieto-Alvarez David Aaron*,1 Zamudio-Rivera Luis S., ${ }^{*, 1}$ Hernández-Altamirano Raúl, ${ }^{2}$ \\ Mena-Cervantes Violeta $\mathrm{Y}^{2}$ Barba Victor $^{3}$ and Flores-Sandoval César ${ }^{1}$ \\ 1 Instituto Mexicano del Petróleo, Eje Central Lázaro Cárdenas 152, Col. San Bartolo Atepehuacan, México D.F. 07730, México. \\ 2 Centro Mexicano para la Producción más Limpia, Instituto Politécnico Nacional, Avenida Acueducto s/n, Colonia La Laguna \\ Ticomán, México, D.F., 07340, Mexico. \\ 3 Centro de Investigaciones Químicas Universidad Autónoma del Estado de Morelos, Av. Universidad 1001 Col. Chamilpa \\ 62209 Cuernavaca, Morelos, México. \\ * Corresponding Author: Tel 01 5591758134.E-mail: nietodav@unam.mx, lzamudio@imp.mx
}

Received June 16, 2016; Accepted October 12, 2016.

\begin{abstract}
The synthesis of novel di- $n$-butyl [bis (alkyl-aminopropionic acid)]tin (IV) (alkyl = octyl, dodecyl, octadecyl) $2 \mathbf{a - 2}$ is reported. The complexes were characterized by ${ }^{1} \mathrm{H},{ }^{13} \mathrm{C},{ }^{119} \mathrm{Sn}$ NMR, IR, MS and elemental analyses. For compound 2a the ${ }^{119} \mathrm{Sn}$ NMR showed the presence of five signals suggesting the existence of a mixture of five hexa-coordinated species in equilibrium, two trans (I, II) and three cis (III, IV, V). In contrast, the compounds $\mathbf{2 b}$ and $\mathbf{2 c}$ present only unique hexa-coordinated specie.
\end{abstract}

Keywords: Diorganotin; Sn (IV) complex; tin; organotin; spectroscopy.

\section{Introduction}

Organotin compounds have been extensively studied in the structural chemistry. For organotin (IV) compounds present frequently the formation of polyhedra with tetrahedral, trigonal-bipyramidal, octahedral and pentagonal-bipyramidal coordination geometries, the final coordination number depends strongly on the number of organic substituents attached to tin atom and the nature of the ligands [1-6].

The organotin (IV) compounds and them derives exhibit antitumor activity [7, 8], biocides [9], material with non-linear optical properties [10], fluorescence probes for DNA traces [11], model systems like nucleotides [12], amino acids [13], peptides [14] and corrosion inhibitors [15].

In particular, diorganotin (IV) compounds derived from ligands containing nitrogen and oxygen donor atoms present increasing number of reports, mainly derivates of aminoacids and analogues have been investigated $[16,17]$. Our current interest in the synthesis of organotin compounds and structural analysis [18-22], prompted us to extend our investigation in the synthesis of new organotin (IV) compounds, which could have corrosion inhibitors properties [23].

This paper describes the synthesis of three new di- $n$-butyl [bis (alkyl-aminopropionic acid)]tin (IV) (alkyl = octyl, dodecyl and octadecyl) 2a-2c, by the reaction of di-n-butyl (IV) oxide and alkyl aminopropionic acid (alkyl = octyl, dodecyl
Resumen: Se reporta la síntesis de nuevos di-n-butil [bis (alquil-ácido aminopropiónico)] de estaño (IV) (alquil = octil, dodecil y octadecil) 2a-2c. Los complejos fueron caracterizados por ${ }^{1} \mathrm{H},{ }^{13} \mathrm{C},{ }^{119} \mathrm{Sn} \mathrm{RMN}$, IR, MS y análisis elemental. Para el compuesto $2 \mathbf{a}$ el espectro de ${ }^{119} \mathrm{Sn}$ RMN muestra la presencia de cinco señales sugiriendo la existencia de cinco especies hexa-coordinadas en equilibrio, dos trans (I, II) y tres cis (III, IV, V). En contraste, los compuestos $\mathbf{2 b}$ y $\mathbf{2 c}$ presentan solo una especie hexa-coordinada.

Palabra clave: Diorganoestaño; complejos de Sn (IV); estaño, organoestaño; espectroscopía.

and octadecyl) 1a-1c in a 1:2 molar ratio. All compounds were characterized by ${ }^{1} \mathrm{H},{ }^{13} \mathrm{C},{ }^{119} \mathrm{Sn}$ NMR, infrared spectroscopy, mass spectrometry and elemental analyses.

\section{Results and Discussion}

Herein we report the reaction of alkyl aminopropionic acids 1a1c, with di- $n$-butyltin (IV) oxide in a 2:1 ratio to obtain di- $n$ butyl [bis (alkyl-aminopropionic acid)] tin (IV) 2a-2c as white solids (Fig. 1). The compounds 1a-1c were obtained through the reaction of alkyl amine (alkyl = octyl, dodecyl and octadecyl) and acrylic acid [24].

The ${ }^{1} \mathrm{H}$ NMR spectra in $\mathrm{CDCl}_{3}$ of all the compounds $\mathbf{2 a - 2 c}$ ( ${ }^{1} \mathrm{H}$ NMR data are summarized in Table 1 ) show only one set of signal for each magnetically equivalent $\mathrm{H}$ nucleus, thus both $(n-\mathrm{Bu})_{2} \mathrm{Sn}$ proton and those of the ligands are in 1:2 ratio, respectively. For $\mathbf{2 b}$ and $\mathbf{2 c}$ compounds, this indicate the formation of unique species or a fast-exchanging equilibrium on the NMR time scale (Support information). For the compound 2b for example, the $\mathrm{H} 3$ and $\mathrm{H} 4$ (3.008 and $2.823 \mathrm{ppm}$ ) proton appeared as broad signals at higher field $(\Delta \delta=0.05$ and 0.083$)$ with respect to the free ligand $\mathbf{1 b}$ (Support information). This suggests a shielding of these protons upon coordination giving evidence for the formation of a Sn-O bonded and $\mathrm{NH} \rightarrow \mathrm{Sn}$ coordination bond. 


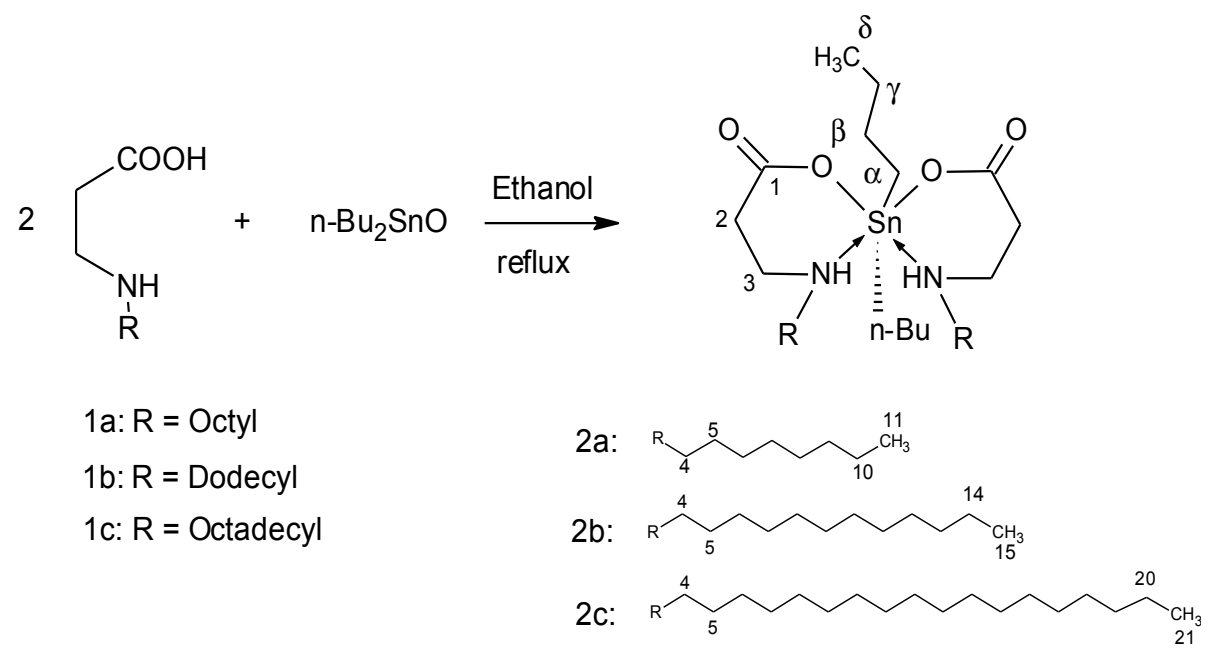

Fig. 1. Synthesis of new di- $n$-butyl [bis (alkyl-aminopropionic acid)] tin (IV).

Table 1. Chemical shift of ${ }^{1} \mathrm{H}$ NMR for compounds $2 \mathrm{a}-2 \mathrm{c}$.
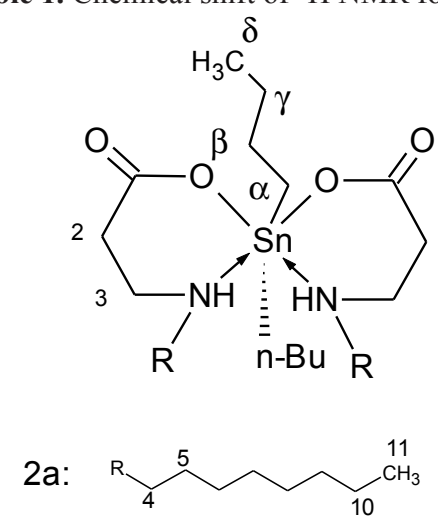

$2 b: \overbrace{5}^{4} \overbrace{\overbrace{15}^{C_{3}}}^{14}$

$2 \mathrm{c}: \overbrace{5}^{4} \overbrace{\underbrace{\mathrm{CH}_{3}}_{21}}^{20}$

\begin{tabular}{|c|c|c|c|}
\hline \multicolumn{4}{|l|}{ Compound } \\
\hline & $2 \mathrm{a}$ & $2 b$ & $2 \mathrm{c}$ \\
\hline $\mathrm{H} 2$ & $2.504(\mathrm{~b})$ & $2.504(b)$ & $2.367(b)$ \\
\hline H3 & $3.045(\mathrm{~b})$ & 3.008 (b) & $2.914(\mathrm{~m})$ \\
\hline $\mathrm{H} 4$ & $2.869(b)$ & $2.823(b)$ & $2.725(\mathrm{~m})$ \\
\hline H5 & $1.662(b)$ & $1.635(b)$ & $1.532(\mathrm{~b})$ \\
\hline H6-H10 & $1.262(\mathrm{~m})$ & & \\
\hline H11 & $0.877(\mathrm{t}, \mathrm{J}=6.6)$ & & \\
\hline H6-H14 & & $1.242(\mathrm{~m})$ & \\
\hline H15 & & $0.869(\mathrm{t}, \mathrm{J}=6.6)$ & \\
\hline H6-H19 & & & $1.135(\mathrm{~m})$ \\
\hline $\mathrm{H} 20$ & & & $0.744(\mathrm{~m})$ \\
\hline$H \alpha-H \beta$ & $1.215(\mathrm{~m})$ & $1.242(\mathrm{~m})$ & $1.135(\mathrm{~m})$ \\
\hline $\mathrm{H} \gamma$ & $1.180(\mathrm{~m})$ & $1.242(\mathrm{~m})$ & $1.135(\mathrm{~m})$ \\
\hline $\mathrm{H} \delta$ & $0.877(\mathrm{t}, \mathrm{J}=6)$ & $0.869(\mathrm{t}, \mathrm{J}=6.6)$ & $0.744(\mathrm{~m})$ \\
\hline
\end{tabular}

$\mathrm{d}\left({ }^{1} \mathrm{H}\right)$ relative to $\mathrm{Si}\left(\mathrm{CH}_{3}\right)_{4}$; solvent $\mathrm{CDCl}_{3}$. b: broad; m: unresolved pattern; t: triplet and $\mathrm{J} \mathrm{Hz}$.
For the compound $\mathbf{2 b}$ the ${ }^{13} \mathrm{C}$ NMR spectrum in $\mathrm{CDCl}_{3}$, the carbon $\mathrm{C} 3$ and $\mathrm{C} 4$ appeared as broad signals (47.623 and 44.748 $\mathrm{ppm})$ at low field $(\Delta \delta=0.521$ and 0.170$)$ with respect to the free ligand $\mathbf{1 b}$, the chemical shift of these carbons gave evidence for the formation of $\mathrm{NH} \rightarrow \mathrm{Sn}$ coordination bond. Likewise, the chemical shift of the signals of the compound $\mathbf{2 b}$ the carbons $\mathrm{C} 1$ and $\mathrm{C} 2$ appeared as broad signals (177.242 and $33.154 \mathrm{ppm})$ with respect to the carbons of free ligand $\mathbf{1 b}(\Delta \delta=$ 0.316 and 1.254) giving evidence for the formation of $\mathrm{Sn}-\mathrm{O}$ bonded. The ${ }^{13} \mathrm{C}$ NMR data are summarized in Table 2.

All compounds (2a-2c) exhibited ${ }^{1} \mathrm{~J}\left({ }^{119} \mathrm{Sn}-{ }^{13} \mathrm{C}\right)$ and ${ }^{2} \mathrm{~J}\left({ }^{117} \mathrm{Sn}-{ }^{13} \mathrm{C}\right)$ coupling $749 / 608,720 / 690$ and $705 / 633 \mathrm{~Hz}$ respectively within the range of trans six-coordinated tin compound [16-19] The ${ }^{119} \mathrm{Sn}$ NMR spectra of $\mathbf{2 b}$ and $\mathbf{2 c}$ at room temperature in chloroform show only one signal at -203.96 and $-204.20 \mathrm{ppm}$ respectively. This can indicate unique species or a fast exchanging equilibrium, on the NMR time scale. The chemical shifts are within the range of di- $n$-butyl (IV) hexacoordinated compounds [3-6, 18-22]. Neverthelees, for compound 2a, the ${ }^{119} \mathrm{Sn}$ NMR spectrum show five signals in ca. 0.9:1.0:1.1:1.5:1.0 ratio, $\delta-176.21,-186.10,-194.50$, -204.37 and $-215.91 \mathrm{ppm}$ associate to the hexa-coordinated species, this result suggested the existence of a mixture of an equilibrium between five different hexacoordinated isomers, two trans (I, II) and three cis (III, IV, V) in solution at room temperature, the isomerism is attributed a different arrangement of the ligands [28, 21] as show in Fig. 2, a possible explanation in formation of hexacoordinate isomers due to the presence of chain short, giving as a result the existence of equilibrium dynamic.

The IR spectra for the compounds $2 \mathbf{a}-\mathbf{2 c}$ exhibit one $\mathrm{v}_{(\mathrm{C}=\mathrm{O})}$ carbonyl band in $1654 \mathrm{~cm}^{-1}$. Also a broad band one of them assigned to the N-H in $1566 \mathrm{~cm}^{-1}$ and other due Sn-O band is observed in $430 \mathrm{~cm}^{-1}$.

The mass spectra in all three cases for $\mathbf{2 a - 2} \mathbf{c},(15 \mathrm{eV}$ IE) displayed the presence of molecular ion confirming of the 
Table 2. Chemical shift of ${ }^{13} \mathrm{C}$ NMR for compounds $2 \mathrm{a}-2 \mathrm{c}$.

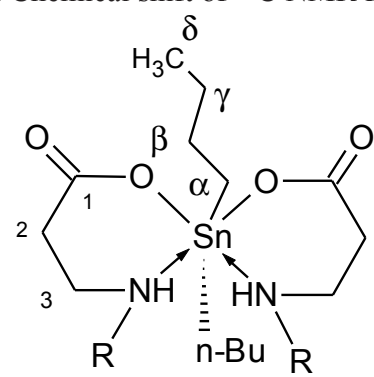

2a: $\overbrace{4}^{\mathrm{R} \underbrace{11}_{10}} \mathrm{CH}_{3}^{11}$

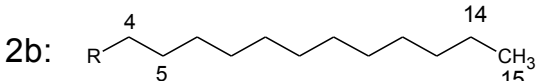

$2 \mathrm{C}: \overbrace{5}^{4} \overbrace{\substack{\mathrm{CH}_{3} \\ 21}}^{20}$

\begin{tabular}{|c|c|c|c|}
\hline \multicolumn{4}{|l|}{ Compound } \\
\hline & $2 \mathrm{a}$ & $2 b$ & $2 c$ \\
\hline $\mathrm{C} 1$ & 177.242 & 177.242 & 177.037 \\
\hline $\mathrm{C} 2$ & 33.066 & 33.154 & 32.524 \\
\hline $\mathrm{C} 3$ & 47.579 & 47.623 & 47.343 \\
\hline $\mathrm{C} 4$ & 44.723 & 44.782 & 44.460 \\
\hline $\mathrm{C} 5$ & 31.646 & 31.807 & 31.821 \\
\hline C6 & 29.117 & & \\
\hline $\mathrm{C} 7$ & 29.068 & & \\
\hline $\mathrm{C} 8-\mathrm{C} 9$ & 26.813 & & \\
\hline $\mathrm{C} 10$ & 22.507 & & \\
\hline $\mathrm{C} 11$ & 13.995 & & \\
\hline C6-C11 & & $29.257-29.537$ & \\
\hline $\mathrm{C} 12-\mathrm{C} 13$ & & $26.710-26.888$ & \\
\hline $\mathrm{C} 14$ & & 22.581 & \\
\hline $\mathrm{C} 15$ & & 14.014 & \\
\hline C6-C17 & & & $29.156-29.626$ \\
\hline $\mathrm{C} 18$ & & & 26.696 \\
\hline $\mathrm{C} 19$ & & & 26.154 \\
\hline $\mathrm{C} 20$ & & & 22.581 \\
\hline $\mathrm{C} 21$ & & & 14.014 \\
\hline $\mathrm{C} \alpha-$ & $\begin{array}{l}27.399 \\
{[749 / 608]}\end{array}$ & $\begin{array}{l}27.487 \\
{[720 / 690]}\end{array}$ & $\begin{array}{l}27.370 \\
{[705 / 633]}\end{array}$ \\
\hline$C \beta-C \gamma$ & 27.252-27.399 & $27.106-27.252$ & $27.062-27.208$ \\
\hline $\mathrm{C} \delta$ & 13.560 & 13.604 & 13.574 \\
\hline
\end{tabular}

Chemical shifts in ppm respect to TMS ${ }^{1} \mathrm{~J}\left({ }^{13} \mathrm{C}-{ }^{119} \mathrm{Sn}\right),{ }^{2} \mathrm{~J}\left({ }^{13} \mathrm{C}-{ }^{117} \mathrm{Sn}\right)$ coupling constant between square brackets. formation of the products, the fragmentation process start with the loss of a ligand, followed by loss of $n$-butyl groups (yielding the base peak for $\mathbf{2 a}$ ), and later loss of $\mathrm{Sn}$ atom giving the base peak for compounds $\mathbf{2 b}$ and $\mathbf{2 c}$. The spectra show others fragment ion and a possible fragmentation pattern is given in Fig. 3.

\section{Experimental section}

\section{Materials}

The reagents were purchased from Aldrich Co. Melting points were determined in open capillaries on Electrothermal melting apparatus (UK) and are uncorrected. IR spectra were recorded on Bruker Tensor-27 FT-IR using KBr pellets. ${ }^{1} \mathrm{H},{ }^{13} \mathrm{C}$ and ${ }^{119} \mathrm{Sn}$ NMR spectra were recorded on VARIAN Mercury 200-BB spectrometer. The ${ }^{1} \mathrm{H}$ and ${ }^{13} \mathrm{C}$ chemical shifts [ppm] are relative to internal $\mathrm{SiMe}_{4}$ (TMS) and the ${ }^{119} \mathrm{Sn}$ chemical shifts $\mathrm{d}$ [ppm] are relative to internal $\mathrm{SnMe}_{4}$. Results are presented as, chemical schift in ppm, multiplicity coupling constants in Hz, number of protons, proton's position. Multiplicities are shown as the abbreviations: s (singlet), d (doublet), $\mathrm{t}$ (triplet), and $\mathrm{m}$ (multiplet). Mass spectra were obtained in HP $5973 \mathrm{MSD}$ eV $=15.2$ (Direct insertion probe). Elemental analyses were performed on CHNS analysis in Perkin Elmer Series II 2400. Solvent were commercially available reagent grade.

\section{Synthesis of alkyl-aminopropionic acid 1a-3a (alkyl = octyl, docecyl and octadecyl)}

Octyl-aminopropionic acid 1a: $5.0 \mathrm{~g}(0.038 \mathrm{~mol})$ of octylamine was slowly added $3.35 \mathrm{~g}(0.046 \mathrm{~mol})$ of acrylic acid; the reaction was placed in flask equipped with a magnetic stirred, thermometer and reflux system. The reaction was carried to 90$95{ }^{\circ} \mathrm{C}$ during 2 hours. After being cooled to room temperature the residue was treated with hexane, the solution is filtered and the residue was treated with chloroform, the solution was filtered and the solvent was evaporated under vacuum to yield $7.82 \mathrm{~g}(95 \%)$ of compound $\mathbf{1 a}$ as white solid. Yield 95\%; mp 86-87 ${ }^{\circ} \mathrm{C}$; IR $\left(\mathrm{KBr}, v_{\max } / \mathrm{cm}^{-1}\right) 3375(\mathrm{~N}-\mathrm{H}), 1655(\mathrm{C}=\mathrm{O}) ;{ }^{1} \mathrm{H}$ NMR (200MHz, $\left.\mathrm{CDCl}_{3}, \delta \mathrm{ppm}\right): 0.856(\mathrm{t}, J=6.6 \mathrm{~Hz}, 3 \mathrm{H}, \mathrm{H}-11)$, 1.241 (m, 10H, H-6 to H-10), 1,721 (m, 2H, H-5), 2.506 (t, $J=$ $5.5 \mathrm{~Hz}, 2 \mathrm{H}, \mathrm{H}-2), 2.895$ (t, $J=7.8 \mathrm{~Hz}, 2 \mathrm{H}, \mathrm{H}-4), 3.055$ (t, $J=5.5$ $\mathrm{Hz}, 2 \mathrm{H}, \mathrm{H}-3) ;{ }^{13} \mathrm{C} \mathrm{NMR}\left(50 \mathrm{MHz}, \mathrm{CDCl}_{3}, \delta \mathrm{ppm}\right) ; 176.920(\mathrm{C}-$ 1), 46.964 (C-3), 44.518 (C-4), 31.792 (C-2), 31.675 (C-5), 29.068 (C-6, C-7), 26.710 (C-8), 26.169 (C-9), 22.566 (C-10), 14.043 (C-11); elemental analysis: $\mathrm{C}_{11} \mathrm{H}_{23} \mathrm{NO}_{2}$ Calc.: $\mathrm{C}$ 65.97, H 12.22, N 6.95; found: C 65.65, H 12.18, N 6.94.

Dodecyl-aminopropionic acid 1b: $5.0 \mathrm{~g}(0.027 \mathrm{~mol})$ of dodecylamine and $2.3 \mathrm{~g}(0.032 \mathrm{~mol})$ of acrylic acid gave $6.52 \mathrm{~g}$ (94\%) of compound $\mathbf{1 b}$ as white solid. Yield $94 \%$; $\mathrm{mp} 89-90{ }^{\circ} \mathrm{C}$; IR $\left(\mathrm{KBr}, v_{\max } / \mathrm{cm}^{-1}\right) 3374(\mathrm{~N}-\mathrm{H}), 1655(\mathrm{C}=\mathrm{O}) ;{ }^{1} \mathrm{H}$ NMR (200MHz, $\left.\mathrm{CDCl}_{3}, \delta \mathrm{ppm}\right): 0.879$ (t, $\left.J=6.6 \mathrm{~Hz}, 3 \mathrm{H}, \mathrm{H}-15\right)$, 


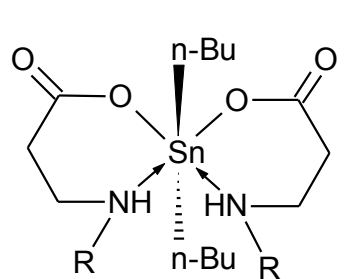

।

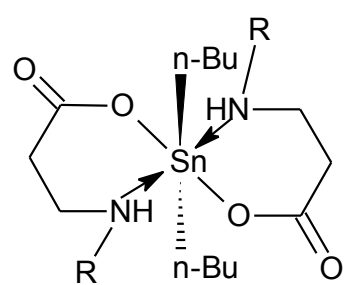

II

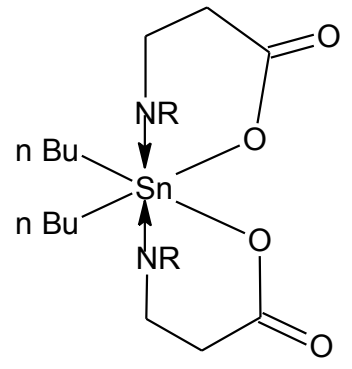

III

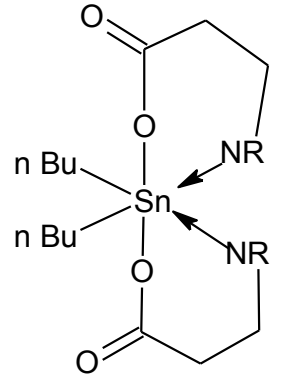

IV

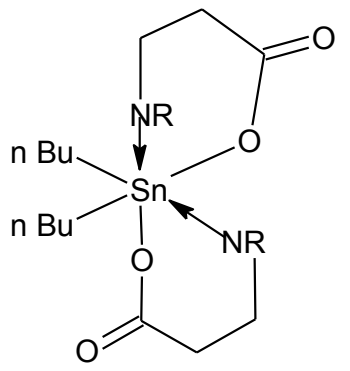

$\mathrm{V}$

Fig. 2. Hexacoordinated isomers for the compound 2a.

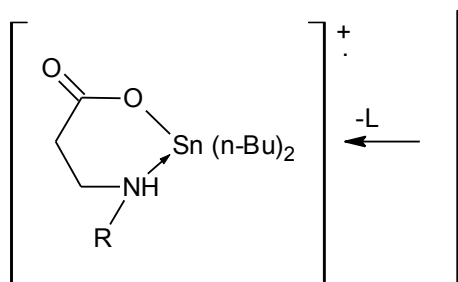

$$
\begin{aligned}
& \mathrm{m} / \mathrm{e}(\%) \\
& \text { 2a: } R=434(28) \\
& \text { 2b: } R=491 \text { (36) } \\
& \text { 2c: } R=574(10)
\end{aligned}
$$$$
\downarrow-n-B u
$$

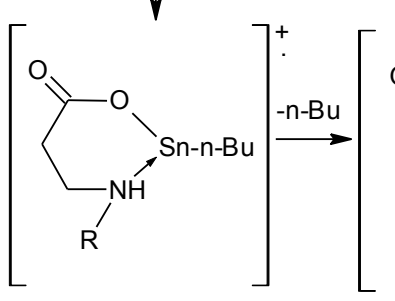

$$
\mathrm{m} / \mathrm{e}(\%)
$$

2a: $R=376(80)$

$2 \mathrm{~b}: \mathrm{R}=432(26)$

2c: $R=516(4)$

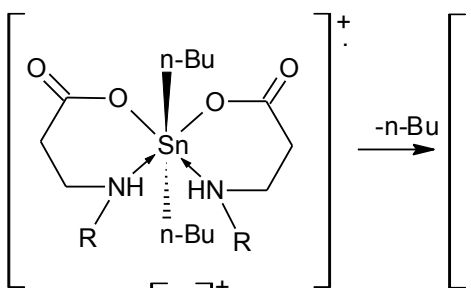

$[\mathrm{M}+1]^{+}$. 2a: $R=636$

$2 b: R=748$

2c: $R=916$<smiles></smiles>

$\mathrm{m} / \mathrm{e}(\%)$

2a: $R=578(14)$

$2 \mathrm{~b}: \mathrm{R}=690(6)$

2c: $R=858(2)$
1.250 (m, 18H, H-6 to H-14), 1,746 (m, 2H, H-5), 2.522 (t, $J=$ $6.0 \mathrm{~Hz}, 2 \mathrm{H}, \mathrm{H}-2), 2.906$ (t, $J=7.8 \mathrm{~Hz}, 2 \mathrm{H}, \mathrm{H}-4), 3.057$ (t, $J=6.0$ $\mathrm{Hz}, 2 \mathrm{H}, \mathrm{H}-3) ;{ }^{13} \mathrm{C}$ NMR (50MHz, $\left.\mathrm{CDCl}_{3}, \delta \mathrm{ppm}\right) ; 176.926(\mathrm{C}-$ 1), 47.102 (C-3), 44.612 (C-4), 31.900 (C-2), 31.564 (C-5), 29.103-29.613 (C-6 to C-11), 26.731 (C-12), 26.394 (C-13),
22.689 (C-14), 14.137 (C-15); elemental analysis: $\mathrm{C}_{15} \mathrm{H}_{31} \mathrm{NO}_{2}$ Calc.: C 67.42, H 12.45, N 5.26; found: C 67.46, H 12.50, N 5.26.

Octadecyl-aminopropionic acid 1c: $5.0 \mathrm{~g}(0.018 \mathrm{~mol})$ of octadecylamine and $1.6 \mathrm{~g}(0.022 \mathrm{~mol})$ of acrylic acid gave $5.52 \mathrm{~g}$ 
(90\%) of compound 1c as white solid. Yield 90\%; mp 91-92 ${ }^{\circ} \mathrm{C}$; IR (KBr, $\left.v_{\max } / \mathrm{cm}^{-1}\right) 3374(\mathrm{~N}-\mathrm{H}), 1655$ (C-O); ${ }^{1} \mathrm{H}$ NMR (200MHz, $\left.\mathrm{CDCl}_{3} \delta \mathrm{ppm}\right): 0.871$ (t, $\left.J=6.6 \mathrm{~Hz}, 3 \mathrm{H}, \mathrm{H}-21\right), 1.244$ (m, 26H, H-6 to H-20), 1,740 (m, 2H, H-5), 2.522 (t, $J=6.0 \mathrm{~Hz}$, 2H, H-2), 2.900 (t, $J=7.8 \mathrm{~Hz}, 2 \mathrm{H}, \mathrm{H}-4), 3.059$ (t, $J=6.0 \mathrm{~Hz}$, $2 \mathrm{H}, \mathrm{H}-3) ;{ }^{13} \mathrm{C} \mathrm{NMR}\left(50 \mathrm{MHz}, \mathrm{CDCl}_{3}, \delta \mathrm{ppm}\right) ; 176.920(\mathrm{C}-1)$, 47.052 (C-3), 44.548 (C-4), 31.909 (C-2), 31.734 (C-5), 29.12729.698 (C-6 to C-17), 26.740 (C-18), 26.227 (C-19), 22.683 (C20), 14.116 (C-21); elemental analysis: $\mathrm{C}_{21} \mathrm{H}_{43} \mathrm{NO}_{2}$ Calc.: $\mathrm{C}$ 73.06, H 13.26, N 4.15; found: C 72.99, H 13.45, N 4.11.

\section{Synthesis of di- $\boldsymbol{n}$-butyl [bis(alkyl-aminopropionic acid)]tin (IV) 2a-2c (alkyl = octyl, docecyl and octadecyl)}

Complex di- $\boldsymbol{n}$-butyl [bis(octyl-aminopropionic acid)] tin (IV) 2a: A solution of $0.5 \mathrm{~g}(0.00248 \mathrm{~mol})$ of $1 \mathbf{a}$ in $100.0 \mathrm{ml}$ of ethanol was placed in flask equipped with a magnetic stirred and dean-Stark trap and $0.3 \mathrm{~g}(0.0012 \mathrm{~mol})$ of di- $n$-butyltin (IV) oxide were added. The suspension was refluxed during 10 hours. After being cooled to room temperature, the solvent was evaporated under vacuum. The residue was treated with chloroform, the solution was filtered and the solvent was evaporated under vacuum to yield $1.25 \mathrm{~g}(80 \%)$ of compound $2 \mathbf{a}$ as yellow solid. Yield 80\%; mp 90-91 ${ }^{\circ} \mathrm{C}$; IR $\left(\mathrm{KBr}, v_{\max } / \mathrm{cm}^{-1}\right) 1654$ $(\mathrm{C}=\mathrm{O}), 1566(\mathrm{~N}-\mathrm{H}), 430(\mathrm{Sn}-\mathrm{O}) ;{ }^{1} \mathrm{H} \mathrm{NMR}\left(200 \mathrm{MHz}, \mathrm{CDCl}_{3}\right.$, $\delta \mathrm{ppm}): 0.877$ (t, $J=6.6 \mathrm{~Hz}, 6 \mathrm{H}, \mathrm{H}-11), 1.262(\mathrm{~m}, 10 \mathrm{H}, \mathrm{H}-6$ to H-10), 1,662 (broad, 2H, H-5), 2.504 (broad, 2H, H-2), 2.869 (b, 2H, H-4), 3.045 (b, 2H, H-3), 1.215 (m, 4H, H $\alpha-H \beta$ ), 1.180

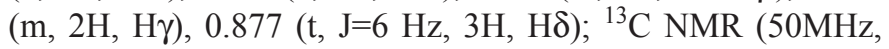
$\left.\mathrm{CDCl}_{3}, \delta \mathrm{ppm}\right) ; 177.242$ (C-1), 47.579 (C-3), 44.723 (C-4), 33.066 (C-2), 31.646 (C-5), 29.117 (C-6), 29.068 (C-7), 26.813 (C-8, C-9), 22.507 (C-10), 13.995 (C-11), 27.399 [Ca, ${ }^{1} \mathrm{~J}\left({ }^{119} \mathrm{Sn}-\right.$ $\left.\left.{ }^{13} \mathrm{C}\right)=749,{ }^{1} \mathrm{~J}\left({ }^{117} \mathrm{Sn}-{ }^{13} \mathrm{C}\right)=608 \mathrm{~Hz}\right], 27.252-27.399 \quad(\mathrm{C} \beta-\mathrm{C} \gamma)$, $13.560(\mathrm{C} \delta) ;{ }^{119} \mathrm{Sn}$ NMR (200MHz, $\left.\mathrm{CDCl}_{3} \delta \mathrm{ppm}\right)-176.21$, -186.10, -194.50, -204.37, -215.91 ppm; elemental analysis: $\mathrm{C}_{30} \mathrm{H}_{62} \mathrm{~N}_{2} \mathrm{O}_{4} \mathrm{Sn}$ Calc.: C 53.90, $\mathrm{H}$ 10.44, $\mathrm{N} 4.32$; found: $\mathrm{C}$ 53.79, H 10.52, N 4.27.

Complex di- $\boldsymbol{n}$-butyl [bis(dodecyl-aminopropionic acid)] tin (IV) 2 b: $0.5 \mathrm{~g}(0.00194 \mathrm{~mol})$ of $\mathbf{1 b}$ and $0.242 \mathrm{~g}(0.00097 \mathrm{~mol})$ of di- $n$-butyltin (IV) oxide gave $1.15 \mathrm{~g}(81 \%)$ of compound 2b as yellow solid. Yield $81 \%$; mp $91-92{ }^{\circ} \mathrm{C}$; IR (KBr, $v_{\max } /$ $\left.\mathrm{cm}^{-1}\right) 1654(\mathrm{C}=\mathrm{O}), 1566(\mathrm{~N}-\mathrm{H}), 430 \quad(\mathrm{Sn}-\mathrm{O}) ;{ }^{1} \mathrm{H}$ NMR (200MHz, $\left.\mathrm{CDCl}_{3}, \delta \mathrm{ppm}\right): 0.869(\mathrm{t}, J=6.6 \mathrm{~Hz}, 3 \mathrm{H}, \mathrm{H}-15)$, 1.242 (m, 18H, H-6 to H-14), 1,635 (b, 2H, H-5), 2.504 (b, 2H, H-2), 2.823 (b, 2H, H-4), 3.008 (b, 2H, H-3), 1.242 (m,

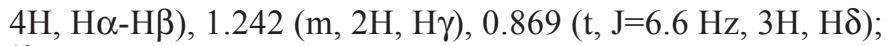
${ }^{13} \mathrm{C}$ NMR (50MHz, $\left.\mathrm{CDCl}_{3}, \delta \mathrm{ppm}\right) ; 177.242$ (C-1), 47.623 (C-3), 44.782 (C-4), 33.154 (C-2), 31.807 (C-5), 29.25729.537 (C-6 to C-11), 26.888 (C-12), 26.710 (C-13), 22.581 $(\mathrm{C}-14), 14.014(\mathrm{C}-15), 27.487\left[\mathrm{C} \alpha,{ }^{1} \mathrm{~J}\left({ }^{119} \mathrm{Sn}-{ }^{13} \mathrm{C}\right)=720\right.$, $\left.{ }^{2} \mathrm{~J}\left({ }^{117} \mathrm{Sn}-{ }^{13} \mathrm{C}\right)=690 \mathrm{~Hz}\right], 27.252-27.106(\mathrm{C} \beta-\mathrm{C} \gamma), 13.604(\mathrm{C} \delta)$; ${ }^{119} \mathrm{Sn}$ NMR (200MHz, $\left.\mathrm{CDCl}_{3}, \delta \mathrm{ppm}\right)-203.96$ ppm; elemental analysis: $\mathrm{C}_{38} \mathrm{H}_{78} \mathrm{NO}_{4} \mathrm{Sn}$ Calc.: C 58.31, H 10.87, N 3.50; found: C 58.33, H 10.85, N 3.48.
Complex di-n-butyl [bis(octadecyl-aminopropionic acid)] tin (IV) 2c: $1.5 \mathrm{~g}(0.0044 \mathrm{~mol})$ of $1 \mathrm{c}$ and $0.547 \mathrm{~g}(0.0022 \mathrm{~mol})$ of di-n-butyltin (IV) oxide gave $2.5 \mathrm{~g}(78 \%)$ of compound $2 \mathrm{c}$ as yellow solid. Yield 78\%; mp $93{ }^{\circ} \mathrm{C}$; IR $\left(\mathrm{KBr}, v_{\max } / \mathrm{cm}^{-1}\right)$ $1654(\mathrm{C}=\mathrm{O}), 1566(\mathrm{~N}-\mathrm{H}), 430(\mathrm{Sn}-\mathrm{O}) ;{ }^{1} \mathrm{H}$ NMR $(200 \mathrm{MHz}$, $\left.\mathrm{CDCl}_{3}, \delta \mathrm{ppm}\right): 0.744(\mathrm{~m}, 3 \mathrm{H}, \mathrm{H}-21), 1.135$ (m, 26H, H-6 to H-20), 1.532 (b, 2H, H-5), 2.367 (b, 2H, H-2), 2.725 (b, 2H,

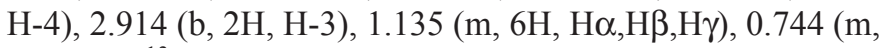
$3 \mathrm{H}, \mathrm{H} \delta) ;{ }^{13} \mathrm{C}$ NMR $\left(50 \mathrm{MHz}, \mathrm{CDCl}_{3}, \delta \mathrm{ppm}\right) ; 177.037$ (C-1), 47.343 (C-3), 44.460 (C-4), 32.524 (C-2), 31.821 (C-5), 29.15629.629 (C-6 to C-17), 26.696 (C-18), 26.154 (C-19), 22.581 $(\mathrm{C}-20), \quad 14.014 \quad(\mathrm{C}-21), \quad 27.370 \quad\left[\mathrm{C} \alpha,{ }^{1} \mathrm{~J}\left({ }^{119} \mathrm{Sn}-{ }^{13} \mathrm{C}\right)=705\right.$, $\left.{ }^{1} \mathrm{~J}\left({ }^{117} \mathrm{Sn}-{ }^{13} \mathrm{C}\right)=633 \mathrm{~Hz}\right], 27.062-27.208(\mathrm{C} \beta-\mathrm{C} \gamma), 13.574(\mathrm{C} \delta)$; ${ }^{119} \mathrm{Sn}$ NMR (200MHz, $\mathrm{CDCl}_{3}, \delta$ ppm) -204.20 ppm; elemental analysis: $\mathrm{C}_{50} \mathrm{H}_{102} \mathrm{~N}_{2} \mathrm{O}_{4} \mathrm{Sn}$ Calc.: $\mathrm{C}$ 73.51, $\mathrm{H}$ 11.06, $\mathrm{N}$ 4.37; found: C 73.19, H 11.11, N 4.42.

\section{Conclusions}

Novel di- $n$-butyl [bis (alkyl-aminopropionic acid)]tin (IV) (al$\mathrm{kyl}=$ octyl, dodecyl and octadecyl) $\mathbf{2 a - 2 c}$ were obtained. The hexacoordinated complexes were characterized by ${ }^{1} \mathrm{H},{ }^{13} \mathrm{C}$, ${ }^{119} \mathrm{Sn}$ NMR, infrared spectroscopy, mass spectrometry and elemental analyses. The compound $2 \mathbf{a}$ showed five hexa-coordinate species indicating the existence of a mixture in equilibrium between two trans (I, II) and three cis (III, IV, V) hexacoordinated isomers. Whereas for the compounds $\mathbf{2 b}$ and $\mathbf{2 c}$ only unique species were observed due to due to steric hindrance of alkyl substituents.

\section{Acknowledgments}

The authors want to acknowledge the Mexican Institute of Petroleum (IMP), Project D.00402 "Escalamiento y evaluación a nivel industrial de un nuevo inhibidor de corrosion para medios básicos característicos de plantas FCC IMP-ICIM-8000”.

\section{References}

1. Holloway, C.E.; Melnik, M. Main Group Met Chem. 2000, 23, 1-147.

2. Willen, R.; Verbruggen I.; Gilen M.; Biesemans, M.; Tiekink, E.R.T. Organometalics. 1998, 17, 6758.

3. Holecek, J.; Nadvornik, H.; Handlir, K.; Lycka, A. Organomet Chem. 1986, 315, 299-308

4. Lycka, A.; Holecek, J.; Nadvornik, H. Main Group Met Chem. 1989, 12, 169-177.

5. Wrackmeyer, B. Ann Rep NMR Spectroscopy, Academic Press, New York. 1985. 16, 73-186.

6. Davies, A.G.; Gielen, M.; Pannell, K.H.; Tiekink, E.R.T. Tin Chemistry. Wiley. 2008, 117-137.

7. Pellerito, L.; Nagy, L. Coord. Chem Rev. 2002, 224, 11-150.

8. Girasolo, M.A.; Rubino, S.; Portanova, P.; Calvaruso, G.; Ruisi, G.; Stocco, G. J Org Chem, 2010, 695, 609-618. 
9. Beraldo, H.; De Lima, G.M. Anti-fungal activity of organotin compounds in: Davis A.G., Gilen M., Pannell K.H. (Eds). Tin Chemistry-Fundamenttals, Frontiers and Application. Wiley, Chichenester, UK. 2008, pp.443-453.

10. Pellerito, L.; Nagy, L. Coord Chem Rev. 2004, 224, 111-150.

11. Lacroix, P.G.; Farfán, N.; Optical propierties of tin-based coordination compounds, in: Davis, A.G.; Gilen, M.; Pannell, K.H. (Eds). Tin Chemistry-Fundamenttals, Frontiers and Application. Wiley, Chichenester, UK. 2008, 351-360.

12. Cassus, E.P.; Machado, S.P.; Wardell, J.L. Appl Organomet Chem. 2007, 21, 203-208.

13. Ma, C.; Zhang, J.; Zhang, R. Hetroatom Chem. 2003, 14, 637-641.

14. Buck, B.; Mascioni, A. J Am Chem Soc. 2003, 125, 13316-13317.

15. Bouhrira, K.; Chetouani, A.; Zerouali, D.; Hammouti, B.; Yahyi, A.; Et-Touhami, A.; Yahyaoui, R.; Touzani, R. Research on Chemical Intermediates. 2014, 40, 569-586.

16. Barroso-Flores, J.; Cea-Flores, Toscano, R.A.; Cogordan J.A. $J$ Org Chem. 2004, 689, 2096-2012.
17. Zamudio-Rivera, L.S.; George-Telles, R.; López-Mendoza, G. Inorg Chem. 2005, 44, 5370-5378.

18. Nieto-Alvarez, D.A.; Jiménez-Cruz, F.; Mancilla, T. Poly. 2005, 24, 1054-1062.

19. Nieto-Alvarez, D.A.; Jiménez-Cruz, F.; Mancilla, T. Poly. 2002, 21, 417-1062.

20. Barba, V.; Zaragoza, J.; Höpfl, H.; Farfan, N.; Beltran, H.I.; Zamudio-Rivera, L.S. J Organomet Chem. 2011, 696, 1949-1956.

21. Luna-Garcia, R.; Damian-Murillo, M.; Barba, V.; Höpfl, H.; Beltran, H.I.; Zamudio-Rivera, L.S. J Organomet Chem. 2009, 692, 3965-3972.

22. Barba, V.; Vega, E.; Luna, R.; Höpfl, H.; Beltran, H.I.; Zamudio-Rivera, L.S. J Organomet Chem. 2007, 692, 731-739.

23. Hernandez-Altamirano, R.; Mena-Cervantes, V.; Chávez-Miyauchi, T.; Nieto-Alvarez, D.A.; Domínguez-Aguilae, M.A.; Zamudio-Rivera, L.S.; Barba, V.; Beltran, H.I. Poly. 2013, 54, 301-307.

24. Hernández; R.; Zamudio, L.S.; Mena. V.Y.; Beltrán, H.; Domínguez, M.; Martínez, J.; Estrada, A. Patente: MX/319760/2014. 